Bartın University Journal of Faculty of Economics and Administrative Sciences, 2021, Volume 12, Issue 24

\title{
Kadın Girişimciliği: Motivasyon Faktörleri Üzerine Bir Araştırma $^{1}$
}

\author{
Özge Betül KIRÇICEK \\ Karamanoğlu Mehmetbey Üniversitesi, Sosyal Bilimler Enstitüsü, İşletme ABD \\ ozdgnozge@gmail.com, OrcID: 0000-0001-6429-8326
}

\section{Doç. Dr. Oğuzhan AYTAR}

Karamanoğlu Mehmetbey Üniversitesi, İktisadi ve İdari Bilimler Fakültesi, İşletme oguzhanaytar@hotmail.com, OrcID ID: 0000-0003-3799-0952

\section{Öz}

Girişimcilik ülkelerin ekonomik ve sosyal gelişimlerine etki eden en önemli faktörlerden biridir. Bu çalışmanın amacı motivasyon kavramı ile kadın girişimciliğini bir arada değerlendirerek, kadınları girişimci olmaya sevk eden motivasyon faktörlerini ortaya koymak ve elde edilen motivasyonel faktörlerin kadın girişimciliği üzerindeki öneminin anlaşılmasını sağlamaktır. Araştırmanın ana kütlesini Konya ilinde faaliyette bulunan bilinçli kadın girişimciler oluşturmaktadır. İletişim kurulan kadın girişimcilere yüz yüze ve internet tabanlı anket formu uygulanmıştır. Elde edilen anket formlarından 188 tanesi değerlendirmeye uygun bulunmuştur. Araştırma sonucunda kadınları girişimciliğe motive eden en önemli faktörün kendini gerçekleştirme isteği, kadınların girişimci olmasını olumsuz yönde etkileyen en önemli faktörün ise cam tavan sendromu olduğu, motivasyonel faktörlerin kadın girişimcilerin yaş değişkenine göre istatistiksel açıdan anlamlı farklılıklar taşıdığı tespit edilmiştir.

Anahtar Kelimeler: Girişimcilik, Kadın Girişimciliği, Motivasyon, Motivasyonel Faktörler.

JEL Sınıflandırması: L26, M13

${ }^{1}$ Bu makale, Özge Betül Kırçiçek'in Karamanoğlu Mehmetbey Üniversitesi, SBE, İşletme ABD'nda Oğuzhan Aytar danışmanlığında savunduğu yüksek lisans tez çalışmasından üretilmiştir 


\title{
Women Entrepreneurship: A Research on Motivation Factors
}

\begin{abstract}
Entrepreneurship is one of the most important factors affecting the economic and social development of countries. The aim of this study is to evaluate the concept of motivation and women entrepreneurship together, to reveal the motivational factors that encourage women to become entrepreneurs and to provide understanding of the importance of the motivational factors obtained on women entrepreneurship. The main population of the research consists of women entrepreneurs operate in Konya. A face-to-face and internetbased questionnaire was applied to women entrepreneurs contacted. 188 of the questionnaire forms obtained were found suitable for evaluation. As a result of the research it was determined that the most important factor motivating women to entrepreneurship was the desire to realize yourself, the least factor motivating women to entrepreneurship was glass ceiling syndrome, that motivational factors differ statistically significant according to age variable of women entrepreneurs.
\end{abstract}

Keywords: Entrepreneurship, Women Entrepreneurship, Motivation, Motivational Factors.

JEL Classification: L26, M13

\section{Giriş}

Girişimcilik konusu yeni ekonomik sistemin en temel bileşenleri arasında yer almaktadır. Girişimcilik; ekonomik potansiyelin kullanılması, kalkınma ve bireysel refahın kaynağı olması ve istihdam olanakları sağlaması açısından oldukça önemli bir işleve sahiptir (Altuntepe, 2019:101; Yeşilçimen, 2020:295). Girişimcilik, toplumun ve işletmeciliğin temelinde bir dönüşüm hareketi oluşturur ve geliştirir. $\mathrm{Bu}$ dönüşüm hareketi verimliliği ve ekonomik büyümeyi olumlu yönde etkileyerek arttırır. Girişimcilikle birlikte dönüşüm ve büyüme için gereken en önemli şey ise yenilikçiliktir. Yenilikçilik; hem piyasa için farklı bir ürün ve hizmetin verimliliğinin artmasını sağlamakta hem de yeni ortaya çıkacak olan işletmeleri yatırım açısından cazip konuma getirmektedir (Özyılmaz, 2016: 24). Yenilikçiliğin girişimcilikle entegrasyonu yeni ekonomilerin gelişimi için kaldıraç görevi üstlenmektedir. Girişimcilik yönünde ilerleyen kişilerin genel olarak özellikleri irdelendiğinde çoğunun benzer özelliklere sahip olduğu hemen dikkat çekmektedir (Cansız, 2007: 59). Bu niteliklerden en yoğun olarak görülenler; yenilikçi ve yaratıcı olma, risk alma, özgüven ve liderlik yeteneği olarak sıralanmaktadır. Girişimciliğin, insana sağladığı esneklik ve uyum, çalışma hayatında yer alan hiçbir sektör tarafından sunulamamaktadır. Girişimci kişilik özellikleri içinde olaylara farklı açılardan bakabilme ve detaylardan bütüne yönelik çıkarımlar yapabilme yeteneği önem taşımaktadır (Soysal, 2010b: 87). Bu yetenek kadın girişimciliğinin klasik girişimcilik faaliyetlerinden sıyrılıp, farklı bir olgu olarak gelişmesine ve kavramsallaşmasına neden olmaktadır. Kadınların sahip olduğu 
özelliklerin girişimcilik faaliyetleri üzerinde fark yaratması konunun bilimsel açıdan incelenmesini gerekli kılmıştır.

Kadın girişimciliği demografik ve ekonomik yapı üzerindeki etkilerinin yanı sıra toplumsal gelişme açısından da stratejik bir öneme sahiptir. Kadınların toplumsal yaşamda farkında olunmayan ihtiyaçlara yönelik çözüm önerileri ve ürünleri geliştirmeleri, zihinsel dönüşümün ve yenilikçiliğin yeni bir boyutta değerlendirilmesine yol açacaktır.

\section{Kadın Girişimciliği ve Kadın Girişimciliğinin Önemi}

Dünya genelinde yaşanan teknolojik dönüşüm ve küreselleşmenin etkisiyle, sosyal ve kültürel yaşam alanında kadınların daha fazla rol almaya başladıkları görülmektedir. Kadınların eğitime vermiş oldukları önem ve farklı bakış açıları pek çok alanda başarılı olmalarını sağlamıştır. Sahip oldukları disiplin, detaycılık ve hassasiyet iş dünyasında kadın girişimciliği adında yeni bir yaklaşımın doğmasına neden olmuştur.

Küreselleşen ve değişen yaşam koşullarına kadınlar çok hızlı uyum göstermişlerdir. Toplumsal açıdan üstlendikleri rollere bir yenisini ekleyerek girişimci kadın yaklaşımını geliştirmişlerdir. Bireysel ihtiyaçları veya zorunlulukları nedeniyle iş dünyasına adım atan kadınlar, ev ve iş gibi iki farklı alanda çalışmak zorunda kalarak ağır bir yükün altına girmişlerdir (Efe, 2016: 25). Kadın girişimci kavramı, sadece ekonomik ve kültürel anlamda gelişmiş olan ülkelerdeki kadın girişimciliğini değil, dünya genelinde kurdukları küçük veya büyük işletmelerle iş hayatına atılan, ülke ekonomisine katkı sunan kadın girişimciliğini ifade etmektedir (Narin vd., 2006: 23). Kadın girişimci teması birçok yazar tarafından farklı şekilde ele alınmaktadır. Kadın girişimci en anlaşılır şekliyle bir işletmeyi kurup, yöneten yani işleten kadın olarak ifade edilmektedir (Keskin, 2014: 73). Literatürde kadın girişimci kavramıyla ilgili çeşitli tanım ve açıklamalar bulunmaktadır. Konumuzda doğrudan ilişkili bu açıklamalardan bazıları şu şekilde sıralanmaktadır:

- Kadın girişimci, işveren olarak işletmenin yönetimsel ve kanuni sorumluluğunu kabullenen, işletmesinin başında duran ve işletmesinde şahsen çalışan kişidir (Bedük, 2005: 111).

- Kadın girişimci, piyasa şartları içerisinde, kendi işletmesinin sahibi olan, kendi başına çalışan veya işletmesinde işçi çalıştıran, ürün veya hizmet üretip pazarlayan, finansal kaynaklarını araştıran, işletmesiyle alakalı acil sorunların üstesinden gelebilen, yeni ve değişkenlik gösteren şartlara adapte olan ve alanında tecrübe sahibi olmaya çalışan kişidir (Yağcı ve Bener, 2005: 86).

- Kadın girişimci, girişimcilik vasıflarını taşıyan ve girişimci olma yolunda gereken çabayı ve özverili çalışmayı gerçekleştirebilen işletme sahibi kadındır (Keskin, 2014: 73). 
İçerisinde bulunduğumuz dönemde kadın girişimciliği ekonomilerin en önemli yapı taşlarından biri olmayı başarmıştır (Yaşar, 2017: 53). Ekonominin gelişimi, işsizliğin azaltılıp istihdamın yaratılması ve güncel rekabet ortamında küresel ölçekli başarılı işletmelerin hayata geçirilmesinde kadın girişimciliğinin çok önemli bir işlevi bulunmaktadır (Soysal, 2010a: 73). Kadınların iş dünyasına girmiş olmaları toplumda kadının önemini arttırarak o toplumun gelişmişlik seviyesini yükselttiği gibi eşit olmayan gelir dağılımının dengelenmesine de imkân sağlamaktadır (Can ve Karataş, 2007: 253).

Kadın girişimciliğin yüksek olduğu, kadınların toplumsal hayatta ve iş dünyasında aktif olarak yer aldığı ülkelerin ekonomik anlamda istikrarı yakaladıkları görülmektedir. Aynı şekilde kadın girişimciliğinin düşük seviyelerde kaldığı, kadınların toplum ve iş hayatında geri plana itildiği ülkelerde ekonominin durgun olduğu hatta gerilemeye başladığı da görülmektedir. Gelişmiş toplumlarda kadınlar ve erkeklerin ekonomik ve sosyal hayata katılımların eşit düzeyde olduğu bilinmektedir (Bozkurt ve Yaşar, 2018:240). Kadınların içinde yer almadığı herhangi bir değişim ve gelişim hareketinin fayda sağlayamayacağı çok açıktır. Bununla birlikte toplumsal kalkınma ve toplumsal iş birliği ve yardımlaşmanın sağlanması açısından da kadın girişimciliğinin önemli bir misyonu üstlendiği görülmektedir. Bu sebeplerden ötürü ekonomik ve sosyal gelişim için kentlerde yaşayan kadın nüfusun yanı sıra kırsal kesimdeki kadınların da toplumsal ve iş hayatında desteklenmesi büyük önem arz etmektedir. Çünkü bir ülkedeki kadın nüfusunun güçlenmesi ekonominin, aile yapısının, toplumsal ve kültürel değerlerin güçlenmesi anlamına gelmektedir (Keskin, 2013: 96-97; Öztürk, 2016: 38).

\section{Motivasyonun Kadın Girişimciliği Üzerindeki Etkisi}

Motivasyon esas itibariyle yaratıcılığın ve girişimciliğin kaynağıdır. Kavram insanların nasıl ve neden böyle davrandıklarına yanıt arayan bir olgudur (Koçel, 2018: 639). İnsanları belirli bir davranışı sergilemeye iten ihtiyaç olarak da ifade edilmektedir. $\mathrm{Bu}$ ihtiyaçlar içsel ve dışsal bir takım motivasyon kaynakları tarafından tatmin edilmektedir (Şimşek ve Çelik, 2018: 79). Motivasyon kavramı, bireyin içinde bulunan yetenek ve becerilerini bir hedef doğrultusunda kullanmasına katkı sağlayan istek, dürtü, heves gibi enerji uyandıran güç şeklinde de tanımlanmaktadır.

Doğru bir amacın belirlenmesi, girişimci olmak isteyen bireyler için en önemli motivasyon kaynaklarından biridir. Belirlenen amaçlara ulaşılması, kendini gerçekleştirme ve başarma hissi gibi bireyin yüksek ihtiyaçlarını tatmin etmesi anlamına gelmektedir. Amaçlarına ulaşarak elde ettiği başarının sosyal çevresi tarafından da takdir edilmesi bireyin tatmin olma derecesini ve hızını arttıracaktır. Dolayısıyla kadınların da girişimci olabilmek için kendilerine uygun bir alanı hedef olarak belirleyip motivasyon kaynaklarını oluşturmaları gerekmektedir (Cici, 2013: 73).

Türkiye'de kadınların iş gücüne katılma oranının düşük olduğu bilinmektedir. Bu nedenle potansiyel girişimci özelliğine sahip kadınların girişimcilik faaliyetlerini doğru ve başarılı bir şekilde yönetmeleri oldukça büyük bir öneme sahiptir. Girişimcilik faaliyetlerinin başarılı bir biçimde devam ettirilebilmesi için ise bireylerin zorluklara 
karşı direncini arttıran motivasyonel kaynakların belirlenmesi gerekmektedir (Özdemir, 2010: 132). Kadın girişimcilerin motivasyon kaynakları genellikle sosyal çevrelerine dayanmaktadır. Son çeyrek yüzyıl içinde kadınların eğitim seviyelerinin yükseldiği ve toplumsal yaşamda daha fazla söz sahibi olmaya başladıkları gözlemlenmektedir. Bu gelişmeler kadınların girişimciliğe daha fazla ilgi duymasına yol açmaktadır. Ayrıca girişimcilik faaliyetlerinin sunduğu ekonomik fursatlar ve yönetsel özgürlük, kadınları girişimci olmaya iten en önemli motivasyon kaynaklarıdır. Birçok kadın girişimci, kendi işine sahip olmanın bireysel bir tatmin ve motive kaynağı olduğuna dikkat çekmektedir (Keskin, 2013: 85).

Kadınları girişimci olmaya sevk eden birçok faktör bulunmaktadır. Maddi imkânsızlıklar kadınları girişimciliğe yönlendiren en temel faktördür. Bunun yanı sıra kendini gerçekleştirme ihtiyacı, kendi iş yerini kurma, belirli bir ücret karşılığında başkasının emrinde çalışmak istememe gibi birçok sebep kadınları girişimciliğe yönlendiren önemli unsurlar arasındadır. Kadın girişimciler ekonomik özgürlüğe sahip olabilmek için sosyal, psikolojik ve maddi açıdan tüm riskleri üstlenirler. Ayrıca çalışma sürelerinin fazla olması gibi nedenlerde kadının girişimci olması önünde bir engel oluşturmaktadır. Bazı kadın girişismciler ise ailevi ilişkilerini güçlendirmek, işi ve ailesi arasında bir bütünlük kurmak amaçları doğrultusunda iş sahibi olmayı istemektedirler (Sinanoğlu, 2005: 57-58; Akehurst, Simarro ve Mas- Tur, 2012: 2493).

Kadınların girişimcilik alanlarında rol oynamak istemelerinin nedenlerini belirleyebilmek için birçok araştırma yapılmıştır. Bu araştırmaların odaklandığı ana temalardan bir diğeri de kadın girişimciliği önündeki engellerdir (Raghuvanshi, Agrawal ve Ghosh, 2017; Wu, Li ve Zhang, 2019). Bu araştırmalar kapsamında kadınları girişimciliğe yönlendirerek kendi işlerini kurmak istemelerine neden olan olumlu ve olumsuz motivasyon kaynaklarının bulunduğu sonucuna ulaşılmıştır. Olumsuz motivatörler kadınları girişimci olmaktan uzaklaştıran sebeplerden oluşurken, olumlu motivatörler ise kadınları girişimci olmaları için cezbeden ve isteklendiren sebeplerden oluşmaktadır (Yetim, 2002: 87; Keskin, 2014: 74). Kadınları girişimciliğe motive eden olumlu ve olumsuz motivatörler aşağıda verilen tabloda belirtilmiştir:

Tablo 1. Kadınları Girişimciliğe Teşvik Eden Olumlu ve Olumsuz Motivatörler

\begin{tabular}{|l|l|}
\hline \multicolumn{1}{|c|}{ OLUMLU MOTIVATÖRLER } & \multicolumn{1}{c|}{$\begin{array}{c}\text { OLUMSUZ } \\
\text { MOTIVATÖRLER }\end{array}$} \\
\hline - Kendini Gerçekleştirme İsteği & - İşsiz Kalma Korkusu \\
- Para Kazanma İsteği & - Cam Tavan Sendromu \\
- Sosyal Statü Edinme İsteği & - Esnek Çalışma Saatleri \\
- Güç Elde Etme İsteği & - İş Doyumsuzluğu \\
- Girişimcilik Güdüsü & - Bağımsız Çalışma Arzusu \\
\hline
\end{tabular}

Kaynak: Özgür, 2019: 28

İhtiyaçlar hiyerarşisinin en üst noktasında bulunan kendini gerçekleştirme ve başarıya ulaşma düzeyi, yeterli maddi imkana sahip kadınlar için teşvik edici bir unsur 
olarak kabul edilebilmektedir. Ekonomik açıdan belirli bir seviyeye ulaşmış ve herhangi bir maddi problemi bulunmayan kadınlar için kendilerini gerçekleştirme ve başarıya ulaşma ihtiyacı, kendi işletmelerini kurmalarına yani girişimci olmalarına sebep olan etkin bir faktördür. Bu faktör girişimciliğin gerektirdiği karakteristik özelliklerden biri olarak da karşımıza çıkmaktadır (Cici, 2013: 80; Ersezer, 2019: 56).

Bireyin, başkalarının hareketlerine yön verebilme, kontrolü altına alabilme ve onları sorumluluğu altında toplayabilme isteği, güç ihtiyacı olarak adlandırılmaktadır. McClelland'ın tanımında bireylerin duyduğu güç gereksinimi iki alanda incelenebilmektedir. Bunlardan ilki olumlu yönde ikna eden ve motive eden güç; diğeri ise olumsuz yönde ve bireyleri itaat etmeye zorlayıp hakimiyeti altına alan güçtür. $\mathrm{Bu}$ nedenle güç elde etmek isteyen ve sağlayacağı ayrıcalıklardan faydalanmak isteyen kadınlarda girişimciliğe ilgi duymakta ve motive olmaktadır (Özyılmaz, 2016: 46).

Girişimci olma yolunda kadınları motive eden unsurlardan bir diğeri işsiz kalma korkusu veya işsizliktir. İşsizlik birey için olumsuz bir durum olarak görülse de esasında girişimci olmaya sevk eden bir motivatördür. Annelik görevleri, doğum izni ve çocuk yetiştirme sorumluluğunu taşımaları düzenli işlerde kadın çalışanların tercih edilme olasılığını düşürmektedir. Bunun yanı sıra yaşanan ekonomik krizlerde küçülmeye giden firmaların ilk olarak işine son verdiği bireyler genellikle kadınlardan oluşmaktadır. Herhangi bir işte çalışan kadınların pek çoğu erkeklere oranla daha kısıtlı imkânlara sahip olmaları nedeniyle problemler yaşamaktadır (Bayraker, 2018: 38).

Cam tavan sendromu; kadınların yönetici statüsünde daha üst mevkilere gelmelerine engel teşkil eden davranışsal veya örgütsel önyargılar nedeniyle ortaya çıkan, görünmeyen ancak varlığı hissedilen engeller şeklinde tanımlanmaktadır. Kadınların iş dünyasında alt ve orta dereceli idari görevlerde bulunması ancak yüksek düzeylerde pek fazla bulunamamaları cam tavan sendromunu doğrular niteliktedir (Orhan ve Scott, 2001: 233; Ersezer, 2019: 55).

İş doyumu bireyin işine karşı beslediği olumlu duyguların bütünüdür. $\mathrm{Bu}$ kuramın zittı olan iş doyumsuzluğu da bireyin işine karşı duyduğu hoşnutsuzluğu belirtmektedir. Çalışma hayatı içerisinde ki bireylerin iş doyumsuzluğu yaşamaları yani yapmış oldukları işten hoşnut olmayıp yapmak istememeleri onları başka bir iş aramaya sevk etmektedir. Dolayısıyla yaşadığı iş doyumsuzluğu nedeniyle mevcut işinden ayrılmak isteyen bireyler için girişimcilik oldukça rasyonel bir seçenek olarak değerlendirilmektedir. Girişimciler kişilik özellikleri itibariyle yeniliğe açık ve yaratıcı kişilerdir. Ancak girişimci ruha sahip bireylerin pek çoğu bu özellikten yoksun yönetici veya liderlerin alt kademesinde çalışmak durumunda kalmaktadırlar. Kadınlar özelinde düşünüldüğünde ise bu tarz yöneticilerin alt kademesinde çalışmanın yanı sıra toplumsal rolleri nedeniyle girişimcilik yolunda pek çok zorlukla karşılaştıkları görülmektedir. İçlerinde barındırdıkları girişimcilik ruhunun bir gereği olan bağımsızlığın etkisiyle gerek kurum içerisinde gerekse toplumsal hayatta kendilerini sınırlayan ve engel olan etkenlerden kurutularak bağımsız bir iş ortamı elde etmeyi hedeflemektedirler. Bu nedenle bağımsız çalışma arzusu pek çok kadın girişimci için motivasyon kaynağıdır (Cici, 2013: 77). 


\section{Metodoloji}

\subsection{Araştırmanın Amacı ve Önemi}

Girişimcilik dünya genelinde kalkınma, istihdam yaratma ve refah düzeyini artırma gibi makro ölçekte olumlu etkileri bulunan bir olgudur. Toplumlar bu etkileri nedeniyle girişimcilik süreçlerine, türlerine, girişimcilik eğitimine özel bir önem atfetmektedirler. Kadın girişimciliği ise kadınların toplumsal hayatta varlık göstermesi, iş hayatına katılması ve kadınlara yönelik dezavantajlı konumun avantaja dönüştürülmesi konusunda hassas bir konudur. Özellikle ülkemizde kadın girişimcilerin sayısının artırılması, kadın girişimciliğinin desteklenmesi ve kadınların girişimciliğe kolaylıkla adım atması için yüksek düzeyde çaba sarf edilmektedir. Dolayısı ile kadınları girişimciliğe yönelten onları motive eden faktörlerin belirlenmesi önem taşımaktadır.

$\mathrm{Bu}$ çalışmanın temel amacı, motivasyon kavramı ile kadın girişimciliğini bir arada değerlendirerek, kadınları girişimci olmaya sevk eden motivasyon kaynaklarını belirleyerek elde edilen motivasyonel faktörlerin kadın girişimciliği üzerindeki öneminin anlaşılmasını sağlamaktır. Bu kapsamda bilinçli kadın girişimcileri olumlu yönde etkileyen faktörler demografik değişkenler açısından yordanmaktadır. Kadın girişimcileri olumlu yönde etkileyen ve cesaretlendiren faktörlerin belirlenmesinin, kadın girişimciliğini destekleyecek eğitim, proje ve süreçlere katkı sunması beklenmektedir.

\subsection{Araştırmanın Varsayımları ve Kısıtları}

Araştırmanın en önemli sınırlılığı, anket verilerinin uygulandığı dönemde ortaya çıkan pandemi sürecidir. Pandemi nedeniyle katılımcılarla yüz yüze görüş̧e gerçekleştirilmesinde büyük zorluklarla karşılaşılmıştır. Bununla birlikte pandemi süreci pek çok kadın girişimcinin işletmesini kapatmasına veya girişimcilik faaliyetlerine ara vermesine neden olmuştur. Dolayısı ile kadın girişimcilerin bu süreçten psikolojik olarak olumsuz yönde etkilendikleri gerçeği de göz önünde bulundurulmalıdır. Araştırmanın bir diğer sınırlılığı ise araştırmanın tek bir il baz alınarak yapılmış olmasıdır. Daha fazla bölgede kadın girişimciyle görüşme sağlanıp sonuçların daha etkili ve geçerli olması gerekmektedir. Ancak bu süreç büyük bir maliyet ve zaman gerektirdiği için araştırma sadece Konya ilinde yürütülmüştür. Araştırmada bulunan tüm sınırllıklar göz önünde bulundurularak anket sorularını cevaplayan kadın girişimcilerin sorulara anlaşılır ve doğru cevaplar verdikleri varsayılmıştır.

\subsection{Ana Kütle ve Örneklem Seçim Metodu}

Araştırma ana kütlesini Konya ilinde faaliyette bulunan bilinçli kadın girişimciler oluşturmaktadır. Bu girişimcilerin özelliği girişimcilik faaliyetlerini aktif olarak sürdürmeleri, girişimcilik konusuna duyarlı olmaları ve kadın girişimciliğini destekleme eğilimine sahip olarak çeşitli kadın girişimcilik platformlarına üye olmalarıdır. Özellikle bu girişimcileri motive eden faktörlerin belirlenmesi çalışma 
amaçlarının daha net ve gerçekçi sonuçlara ulaşması açısından önem taşımaktadır. Bu kapsamda Konya ilinde faaliyet yürüten öncü Girişimci Kadın platformlarıyla görüşülmüş, bu kuruluşlardan Konya Ticaret Odası Kadın Girişimci Kurulu üyesi 179 kadın girişimci, Konya İş Kadınları Derneği üyesi 40 kadın girişimcinin iletişim bilgileri temin edilmiştir. Bu kapsamda istatiksel açıdan tam sayım yöntemi kullanılmış, aktif olan tüm üye kadın girişimcilerle tek tek iletişim kurulmuştur. İletişim kurulan kadın girişimcilere yüz yüze ve internet tabanlı anket uygulanmıştır. Elde edilen anketlerden 188 tanesi değerlendirmeye uygun bulunmuştur. Dolayısı ile evren örneklem uyumu açısından bir kısıt bulunmamaktadır.

\subsection{Veri Kaynakları ve Veri Toplama Yöntemi}

Çalışmada nicel veri toplama yöntemlerinden likert tipi soruların yer aldığı anket yöntemi benimsenmiştir. Anket formu oluşturulmadan önce araştırma konusuna en yakın çalışmalar incelenerek araştırma amacına en uygun ölçek sorularından faydalanılmaya çalışılmıştır. Bu kapsamda Özyılmaz (2016), Öztürk (2016), Özgür (2019) ve Çakmak (2019)'ın “Kadın Girişimciliği”” ile ilişkili çalışmalarındaki anket sorularından faydalanılmıştır.

Anket formu demografik bilgiler ve iş yaşamına ilişkin bilgi ve görüşler başlığı altında on üç (13) çoktan seçmeli; iş kurma aşamasında karşılaşılan sorunlar, başarılı bir girişimcide bulunması gereken özellikler, girişimci olmada etkili sebepler ve motive edici faktörler adında dört başlık altında kırk üç (43) likert tipi sorudan oluşmaktadır. Anket formunun oluşturulmasından sonra yirmi bir kişiden oluşan kadın girişimci grubuyla pilot bir çalışma yürütülmüş anlaşılamayan ve çelişki oluşturan sorular revize edilmiştir. İletişim kurulan katılımcılara araştırmanın amacı hakkında bilgi verilerek, doğru ve rahat bir şekilde cevaplandırmaları istenmiştir. Yüz yüze görüşülerek uygulanan anket sürecinde katılımcılardan gelen sorular cevaplanarak, istenilen konularda açıklama yapılmıştır.

\subsection{Araştırma Bulguları}

\subsubsection{Demografik Bulgular}

Çalışma kapsamında görüşlerine başvurulan kadın girişimcilerin \%5'i 18-23 yaş aralığında, \%13,3'ü 24-29 yaş aralığında, \%20,2'si 30-35 yaş aralığında, \%32,4'ü 36-41 yaş aralığında, \%20,7'si 42-47 yaş aralığında, \%10,1'i 48-53 yaş aralığında, \%2,7'si ise 54 ve üzeri yaş aralığındadır. Katılımcı kadın girişimcilerin çoğunlukla orta yaş grubu içerisinde yer aldıkları görülmektedir. 
Women Entrepreneurship:

Tablo 2. Temel Demografik Bulgular

\begin{tabular}{|c|c|c|c|}
\hline Değişken Grupları & Değişkenler & f & $\%$ \\
\hline \multirow{8}{*}{ Yaş } & $18-23$ & 1 & 0,5 \\
\hline & $24-29$ & 25 & 13,3 \\
\hline & $30-35$ & 38 & 20,2 \\
\hline & $36-41$ & 61 & 32,4 \\
\hline & $42-47$ & 39 & 20,7 \\
\hline & $48-53$ & 19 & 10,1 \\
\hline & 54 ve üzeri & 5 & 2,7 \\
\hline & Toplam & 188 & 100,0 \\
\hline \multirow{7}{*}{ Eğitim Durum } & İlköğretim & 9 & 4,8 \\
\hline & Ortaöğretim & 4 & 2,1 \\
\hline & Lise & 30 & 16,0 \\
\hline & Ön Lisans & 31 & 16,5 \\
\hline & Lisans & 90 & 47,9 \\
\hline & Lisansüstü & 24 & 12,8 \\
\hline & Toplam & 188 & 100,0 \\
\hline \multirow{3}{*}{ Medeni Durum } & Evli & 132 & 70,2 \\
\hline & Bekar & 56 & 29,8 \\
\hline & Toplam & 188 & 100,0 \\
\hline \multirow{6}{*}{ Sermaye Kaynağı } & Kişisel ve Ailevi Kaynaklar & 135 & 71,8 \\
\hline & Banka Kredisi & 30 & 16,0 \\
\hline & $\begin{array}{ll}\text { Arkadaş ve/veya } & \text { Akrabaya } \\
\text { Borçlanma }\end{array}$ & 3 & 1,6 \\
\hline & Diğer Ortaklar & 16 & 8,5 \\
\hline & Diğer & 4 & 2,1 \\
\hline & Toplam & 188 & 100,0 \\
\hline
\end{tabular}

Katılımcı kadın girişimcilerin eğitim durumundaki dağılım incelendiğinde; ilköğretim mezunu olanların oranı $\% 4,8$, ortaöğretim mezunu olanların oranı $\% 2,1$, lise mezunu olanların oranı \%16, ön lisans mezunu olanların oranı $\% 16,5^{\prime}$ tir. Lisans mezunu olanların oranı $\% 47,9$ iken lisansüstü mezunu olanların oranı ise $\% 12,8$ 'dir. Katılımcıların eğitim durumuna ait veriler değerlendirildiğinde en az lisans mezunu olan girişimcilerin örneklemin \%47,9'unu oluşturduğu görülmektedir. Bu durum kadınların eğitim seviyesinin yükseldikçe girişimciliğe olan eğilimlerinin arttığını göstermektedir. Görüşleri alınan kadın girişimcilerin \%70,2'sinin evli, \%29,8'inin ise bekar olduğu görülmektedir. Araştırma kapsamında görüşlerine başvurulan kadın girişimcilerin sermaye kaynakları değerlendirildiğinde; en yüksek oranın $\% 71,8$ ile kişisel ve ailevi kaynaklar olduğu, sıralamayı \%16 banka kredileri ile \%8,5 diğer ortakların izlediği gözlenmektedir. 


\subsubsection{Normal Dağılıma Uygunluk Testleri}

Araştırma kapsamında toplanan verilerin normal dağılıma uygun olup olmadıkları Kolmogorov-Smirnov ve ShapiroWilk testleri ile Skewness ve Kurtosis katsayıları yardımıyla incelenmiş ve tüm ölçeklerdeki maddelerin normal dağılıma uygunluk gösterdiği belirlenmiştir. Dolayısıyla, normal dağılıma sahip olan bu verilerde parametrik analiz tekniklerinin uygulanabileceği sonucuna ulaşılmıştır.

Tablo 3. Cronbach's Alpha Güvenilirlik Analizi

\begin{tabular}{|l|c|c|}
\hline Ölçek Boyutları & İfade Sayısı & $\begin{array}{c}\text { Cronbach's Alpha } \\
\text { Katsayısı }\end{array}$ \\
\hline Girişimci Olmada Etkili Olan Sebepler & 9 &, 710 \\
\hline Girişimcilikte Motivasyon Faktörleri & 10 &, 755 \\
\hline Girişimcilikte Karşılaşılan Sorunlar & 10 &, 772 \\
\hline $\begin{array}{l}\text { Başarılı Bir Girişimcinin Sahip Olması } \\
\text { Gereken Özellikler }\end{array}$ & 13 &, 792 \\
\hline
\end{tabular}

Çalışmada kullanılan ölçeklerin cronbach’s alpha katsayısı 0,70-1,00 aralığında olduğundan dolayı tüm faktörler açısından genel olarak güvenirliğin sağlandığı görülmektedir.

\subsubsection{Kadın Girişimcilerin Tutumlarına Yönelik Bulgular}

Tablo 4'te katılımcıların "girişimci olmada etkili olan sebepler", "girişimcilikte motivasyon faktörleri” ve "başarılı bir girişimcinin sahip olması gereken özellikler" boyutlarına yönelik görüş ortalamaları yer almaktadır.

Tablo 4. Katılımcıların Ölçek İfadelerine Yönelik Görüş Ortalamaları

\begin{tabular}{|c|l|c|c|}
\hline & \multicolumn{1}{|c|}{$\begin{array}{c}\text { 1 (Önemli Değil) } \begin{array}{c}\text { Önemli) 5 } \\
\text { Ön }\end{array} \\
\text { Ort. }\end{array}$} & $\begin{array}{c}\text { Std. } \\
\text { S. }\end{array}$ \\
\hline \multirow{3}{*}{} & Aile İhtiyaçlarını karş1lamak için & 3,63 & 1,084 \\
\cline { 2 - 4 } & Hedeflerime ulaşabilmek için & 4,61 & 0,616 \\
\cline { 2 - 4 } & İş dünyasına katılmak için & 4,02 & 0,967 \\
\cline { 2 - 4 } & Bilgi ve becerilerimi kullanmak için & 4,61 & 0,649 \\
\cline { 2 - 4 } & Finansal destek ve teşvik verildiği için & 2,22 & 1,075 \\
\cline { 2 - 4 } & Vaktimi değerlendirmek için & 3,85 & 1,137 \\
\cline { 2 - 4 } & Topluma fayda sağlamak için & 4,47 & 0,892 \\
\cline { 2 - 4 } & Mesleğimi yapmak için & 3,94 & 1,004 \\
\cline { 2 - 4 } & Kendi işimin patronu olmak için & 3,99 & 0,843 \\
\hline
\end{tabular}


Women Entrepreneurship:

\begin{tabular}{|c|c|c|c|}
\hline \multirow{10}{*}{ 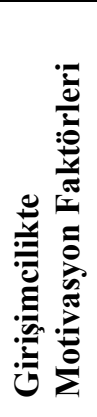 } & Kendini gerçekleştirme isteği & 4,63 & 0,715 \\
\hline & Bağımsız çalışma arzusu & 4,01 & 0,811 \\
\hline & Esnek çalışma saatleri & 3,59 & 0,930 \\
\hline & Para kazanma isteği & 4,31 & 0,764 \\
\hline & Güç elde etme isteği & 3,61 & 1,042 \\
\hline & Sosyal statü edinme isteği & 3,30 & 0,980 \\
\hline & Girişimcilik güdüsü & 4,04 & 0,952 \\
\hline & İş doyumsuzluğu & 1,85 & 1,171 \\
\hline & Cam tavan sendromunu yenmek & 1,49 & 1,042 \\
\hline & İşsiz kalma korkusu & 1,56 & 1,112 \\
\hline \multirow{13}{*}{ 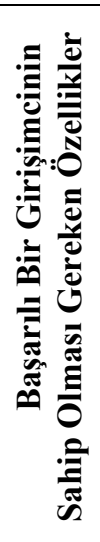 } & Zeki olma & 4,63 & 0,646 \\
\hline & Dürüst olma & 4,86 & 0,480 \\
\hline & Risk alabilme & 4,32 & 0,667 \\
\hline & Çalışkan olma & 4,74 & 0,528 \\
\hline & Güvenilir olma & 4,76 & 0,508 \\
\hline & Vizyon sahibi olma & 4,26 & 0,604 \\
\hline & Özgüven sahibi olma & 4,44 & 0,622 \\
\hline & Kararlı ve azimli olma & 4,65 & 0,561 \\
\hline & Sabırlı ve hoşgörülü olma & 4,53 & 0,666 \\
\hline & Duygusal zekaya sahip olma & 3,04 & 1,101 \\
\hline & Araştırmacı ve gözlemci olma & 4,04 & 0,737 \\
\hline & Yönetim becerisine sahip olma & 4,65 & 0,614 \\
\hline & Etkili iletişim becerisine sahip olma & 4,66 & 0,527 \\
\hline
\end{tabular}

Girişimci olmada etkili olan sebepler ölçeğine ait sonuçlara göre ifadelere verilen yanıtların genel ortalamaları dikkate alındığında, katılımcıların 4,61 ortalamayla "hedeflerime ulaşabilmek" ve "bilgi ve becerilerimi kullanmak" ifadelerine en yüksek önem düzeyini atfettikleri görülmektedir. Bununla birlikte "finansal destek ve teşvik verildiği için" ifadesi ortalamasına bakıldığında destek ve teşviklerin girişimci olmada belirleyici bir rol oynamadığı görülmektedir. Girişimcilikte motivasyon faktörleri ölçeğine ait ifadelere verilen cevaplara göre 4,63'lük bir ortalamaya sahip olan kendini gerçekleştirme isteğinin katılımcıları girişimciliğe motive eden en önemli faktör olduğu görülmektedir. Kadınların özellikle iş hayatında karşılaştıkları cinsiyetçi ve önyargılı yaklaşımlar nedeniyle içlerinde oluşan kendini kanıtlama ve başarma isteğinin bu sonucu ortaya çıkardığı söylenebilir. Katılımcıları en az motive eden faktör ise 1,49'luk ortalama ile cam tavan sendromudur. 1,56'l1k bir ortalamaya sahip olan işsiz kalma korkusu en az motive olunan ikinci faktör olmuştur. Bu durumu katılımcıların bir iş sahibi olmaktan daha çok arzu ettikleri ve severek yapabilecekleri bir işte çalışmak istemelerine bağlamak mümkün olacaktır. Başarılı bir girişimcinin sahip olması gereken özellikler ölçeğine ait ifadelere verilen cevaplar incelendiğinde ise, "dürüst olma" ifadesi en önemli görülen ifade olmuştur. "Duygusal zekaya sahip olma" ifadesinin ise en az önem verilen ifade olduğu görülmektedir. Bununla birlikte genel ortalamaya bakıldığında tüm ifadelere verilen cevaplar birbirine yakın değerlerdedir ve önemli görülmüştür. 
Tablo 5. Katılımcıların İş Kurma Aşamasında Karşılaştıkları Sorunlara Yönelik Görüş Ortalamaları

\begin{tabular}{|c|c|c|c|}
\hline & $\begin{array}{l}1 \text { (Kesinlikle Katılmıyorum) }<<<~>>> \\
\text { (Kesinlikle Katılıyorum) } 5\end{array}$ & Ort. & $\begin{array}{l}\text { Std. } \\
\text { S. }\end{array}$ \\
\hline \multirow{10}{*}{ 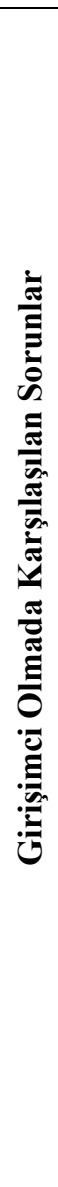 } & $\begin{array}{l}\text { İşimi kurarken sermaye temininde } \\
\text { yaşadım. }\end{array}$ & 3,26 & 1,142 \\
\hline & $\begin{array}{l}\text { İşimi kurarken ailevi sorunlardan dolayı sorun } \\
\text { yaşadım. }\end{array}$ & 1,71 & 0,973 \\
\hline & $\begin{array}{l}\text { İşimi kurarken bürokratik işlemler nedeniyle } \\
\text { sorun yaşadım. }\end{array}$ & 3,16 & 1,165 \\
\hline & $\begin{array}{l}\text { İşimi kurarken mekân seçimi konusunda sorun } \\
\text { yaşadım. }\end{array}$ & 2,61 & 1,068 \\
\hline & $\begin{array}{l}\text { İşimi kurarken personel temininde } \\
\text { yaşadım. }\end{array}$ & 2,77 & 1,146 \\
\hline & $\begin{array}{l}\text { İşimi kurarken materyal temininde } \\
\text { yaşadım. }\end{array}$ & 3,09 & 1,176 \\
\hline & $\begin{array}{l}\text { İşimi kurarken toplumun ön yargıları ve kadına } \\
\text { olan olumsuz bakışından dolayı sorun yaşadım. }\end{array}$ & 2,41 & 1,127 \\
\hline & $\begin{array}{lcccc}\text { İşimi } & \text { kurarken } & \text { bilgi } & \text { eksikliği } & \text { ve } \\
\text { deneyimsizliğimden dolayı sorun yaşadım. } & \end{array}$ & 2,29 & 1,106 \\
\hline & $\begin{array}{l}\text { İşimi kurarken pazarda tanınmamış olmamdan } \\
\text { dolayı sorun yaşadım. }\end{array}$ & 3,16 & 0,992 \\
\hline & $\begin{array}{l}\text { İşimi kurarken toplumsal kültür etkisinden } \\
\text { olumsuz yönde etkilendim. }\end{array}$ & 2,27 & 0,911 \\
\hline
\end{tabular}

Tablo 5'te göre verilen cevapların genel ortalamaları dikkate alındığında kadın girişimciler 3,26 değeri ile en fazla "işimi kurarken sermaye temininde sorun yaşadım" ifadesine katılmışlardır. Bununla birlikte en az katılım sağlanan ifade ise 1,71 değeri ile "işimi kurarken ailevi sorunlardan dolayı sorun yaşadım” ifadesi olmuştur. Dolayısı ile klasik girişimcilik sürecinde yaşanan finansman sorununun, kadın girişimciler açısından da önemli bir sorun olarak geçerliliğini koruduğu görülmektedir. 
Women Entrepreneurship:

\section{Tablo 6. Katılımcıların Ölçek İfadelerine Yönelik Görüşlerinin Demografik Değişkenlere Göre Analizi}

\begin{tabular}{|c|c|c|c|c|c|}
\hline \multicolumn{6}{|c|}{$\begin{array}{l}\mathrm{H}_{1:} \text { Katılımcıların (X)'e yönelik görüşlerinde }(\mathrm{Y}) \text { değişkenine göre anlamlı bir } \\
\text { farklılık vardır. }\end{array}$} \\
\hline $\mathbf{X} / \mathbf{Y}$ & (1) Yaş & (2) Eğitim & $\begin{array}{l}\text { (3) } \\
\text { Çalışan } \\
\text { Sayısı }\end{array}$ & $\begin{array}{l}\text { (4) } \\
\text { Kuruluş } \\
\text { Yılı } \\
\end{array}$ & $\begin{array}{l}\text { (5) } \\
\text { Sermaye } \\
\text { Kaynağı } \\
\end{array}$ \\
\hline \multirow{2}{*}{$\begin{array}{l}\text { Girişimci } \\
\text { Olmada } \\
\text { Etkili Olan } \\
\text { Sebepler }\end{array}$} & $\begin{array}{l}\text { Sig. } \\
\text { (2-tailed) } \\
0,498>0,05\end{array}$ & $\begin{array}{l}\text { Sig. } \\
\text { (2-tailed) } \\
0,192>0,05\end{array}$ & $\begin{array}{l}\text { Sig. } \\
\text { (2-tailed) } \\
0,146>0,05\end{array}$ & $\begin{array}{l}\text { Sig. } \\
\text { (2-tailed) } \\
0,147>0,05\end{array}$ & $\begin{array}{l}\text { Sig. } \\
\text { (2-tailed) } \\
0,003<0,05\end{array}$ \\
\hline & $\begin{array}{l}\mathrm{H}_{1} \text { Red, } \\
\text { Farkl1lik } \\
\text { Yoktur }\end{array}$ & $\begin{array}{l}\mathrm{H}_{1} \text { Red, } \\
\text { Farklılık } \\
\text { Yoktur }\end{array}$ & $\begin{array}{l}\mathrm{H}_{1} \text { Red, } \\
\text { Farklılık } \\
\text { Yoktur }\end{array}$ & $\begin{array}{l}\mathrm{H}_{1} \text { Red, } \\
\text { Farklılık } \\
\text { Yoktur }\end{array}$ & $\begin{array}{l}\mathrm{H}_{1} \text { Kabul, } \\
\text { Farklılık } \\
\text { Vardır }\end{array}$ \\
\hline \multirow{2}{*}{$\begin{array}{l}\text { Girişimcilikte } \\
\text { Motivasyon } \\
\text { Faktörleri }\end{array}$} & $\begin{array}{l}\text { Sig. } \\
\text { (2-tailed) } \\
0,001<0,05\end{array}$ & $\begin{array}{l}\text { Sig. } \\
\text { (2-tailed) } \\
0,602>0,05\end{array}$ & $\begin{array}{l}\text { Sig. } \\
\text { (2-tailed) } \\
0,643>0,05\end{array}$ & $\begin{array}{l}\text { Sig. } \\
\text { (2-tailed) } \\
0,005<0,05\end{array}$ & $\begin{array}{l}\text { Sig. } \\
\text { (2-tailed) } \\
0,425>0,05\end{array}$ \\
\hline & $\begin{array}{l}\mathrm{H}_{1} \text { Kabul, } \\
\text { Farkl1l1k } \\
\text { Vardır }\end{array}$ & $\begin{array}{l}\mathrm{H}_{1} \text { Red, } \\
\text { Farklılık } \\
\text { Yoktur }\end{array}$ & $\begin{array}{l}\mathrm{H}_{1} \text { Red, } \\
\text { Farkl1lık } \\
\text { Yoktur }\end{array}$ & $\begin{array}{l}\mathrm{H}_{1} \text { Kabul, } \\
\text { Farklılık } \\
\text { Vardır }\end{array}$ & $\begin{array}{l}\mathrm{H}_{1} \text { Red, } \\
\text { Farklilık } \\
\text { Yoktur }\end{array}$ \\
\hline \multirow{2}{*}{$\begin{array}{l}\text { Girişimcilikte } \\
\text { Karşılaşılan } \\
\text { Sorunlar }\end{array}$} & $\begin{array}{l}\text { Sig. } \\
\text { (2-tailed) } \\
0,382>0,05\end{array}$ & $\begin{array}{l}\text { Sig. } \\
\text { (2-tailed) } \\
0,226>0,05\end{array}$ & $\begin{array}{l}\text { Sig. } \\
\text { (2-tailed) } \\
0,349>0,05\end{array}$ & $\begin{array}{l}\text { Sig. } \\
\text { (2-tailed) } \\
0,608>0,05\end{array}$ & $\begin{array}{l}\text { Sig. } \\
\text { (2-tailed) } \\
0,339>0,05\end{array}$ \\
\hline & $\begin{array}{l}\mathrm{H}_{1} \text { Red, } \\
\text { Farklilik } \\
\text { Yoktur } \\
\end{array}$ & $\begin{array}{l}\mathrm{H}_{1} \text { Red, } \\
\text { Farklılik } \\
\text { Yoktur } \\
\end{array}$ & $\begin{array}{l}\mathrm{H}_{1} \text { Red, } \\
\text { Farklılık } \\
\text { Yoktur } \\
\end{array}$ & $\begin{array}{l}\mathrm{H}_{1} \text { Red, } \\
\text { Farklılık } \\
\text { Yoktur } \\
\end{array}$ & $\begin{array}{l}\mathrm{H}_{1} \text { Red, } \\
\text { Farklılık } \\
\text { Yoktur } \\
\end{array}$ \\
\hline \multirow{2}{*}{$\begin{array}{l}\text { Başarılı Bir } \\
\text { Girişimcinin } \\
\text { Sahip Olması } \\
\text { Gereken } \\
\text { Özellikler }\end{array}$} & $\begin{array}{l}\text { Sig. } \\
(2 \text {-tailed) } \\
0,254>0,05\end{array}$ & $\begin{array}{l}\text { Sig. } \\
\text { (2-tailed) } \\
0,191>0,05\end{array}$ & $\begin{array}{l}\text { Sig. } \\
\text { (2-tailed) } \\
0,51>0,05\end{array}$ & $\begin{array}{l}\text { Sig. } \\
\text { (2-tailed) } \\
0,011<0,05\end{array}$ & $\begin{array}{l}\text { Sig. } \\
\text { (2-tailed) } \\
0,444>0,05\end{array}$ \\
\hline & $\begin{array}{l}\mathrm{H}_{1} \text { Red, } \\
\text { Farklilik } \\
\text { Yoktur }\end{array}$ & $\begin{array}{l}\mathrm{H}_{1} \text { Red, } \\
\text { Farklılık } \\
\text { Yoktur }\end{array}$ & $\begin{array}{l}\mathrm{H}_{1} \text { Red, } \\
\text { Farklılık } \\
\text { Yoktur }\end{array}$ & $\begin{array}{l}\mathrm{H}_{1} \mathrm{Kabul}, \\
\text { Farklılık } \\
\text { Vardır }\end{array}$ & $\begin{array}{l}\mathrm{H}_{1} \text { Red, } \\
\text { Farklılık } \\
\text { Yoktur }\end{array}$ \\
\hline
\end{tabular}

X: Faktör Grupları Y: (1) Yaş, (2) Eğitim, (3) Çalışan Kişi Sayısı, (4) İşletmenin Kuruluş Yılı, (5) Sermaye Kaynağı

Yapılan Tek Yönlü Varyans Analizi sonucunda; "girişimci olmada etkili olan sebepler" "girişimcilikte karşılaşılan sorunlar" ve "başarılı bir girişimcinin sahip olması gereken özellikler" ölçeklerine ait görüş ortalamalarının yaş durumlarına göre anlamlı bir farklılık göstermediği $(\mathrm{P}>0,05)$, ancak $(\mathrm{P}=0,001<0,05)$ olduğundan katılımcıların yaş grupları ile "girişimcilikte motivasyon faktörleri" ölçeğine yönelik görüş ortalamaları arasında anlamlı bir şekilde fark olduğu belirlenmiştir. Eğitim durumu ve 
işletmede çalışan kişi sayısına göre katılımcıların "girişimci olmada etkili olan sebepler", "girişimcilikte motivasyon faktörleri”, "girişimcilikte karşılaşılan sorunlar" ve "başarılı bir girişimcinin sahip olması gereken özellikler" ölçeklerine yönelik görüş ortalamalarının anlamlı bir farklılık göstermediği $(\mathrm{P}>0,05)$ belirlenmiştir. "Girişimci olmada etkili olan sebepler" ve "girişimcilikte karşılaşılan sorunlar" ölçeklerine ait görüş ortalamalarının işletmenin kuruluş yılına göre anlamlı bir farklılık göstermediği $(\mathrm{P}>0,05)$, "girişimcilikte motivasyon faktörleri" ve "başarılı bir girişimcinin sahip olması gereken özellikler" ölçeklerine ait görüş ortalamalarının ise işletmenin kuruluş yılına göre anlamlı bir farklılık gösterdiği $(\mathrm{P}<0,05)$ belirlenmiştir. Sermaye kaynağına göre ise katılımcıların "girişimcilikte motivasyon faktörleri", "girişimcilikte karşılaşılan sorunlar" ve "başarılı bir girişimcinin sahip olması gereken özellikler" ölçeklerine ait görüş ortalamalarının anlamlı bir farklılık göstermediği $(\mathrm{P}>0,05)$, fakat girişimci olmada etkili olan sebepler" ölçeğine ait ifade görüşleri ile sermaye kaynağı arasında anlamlı bir farklılık olduğu $(\mathrm{P}<0,05)$ belirlenmiştir.

\section{Tablo 7. Katılımcıların Ölçek İfadelerine Yönelik Görüşlerinin Medeni Durum ve Yabancı Dil Bilgisi Değişkenlerine Göre Analizi}

\begin{tabular}{|c|c|c|}
\hline \multicolumn{3}{|c|}{$\begin{array}{l}\mathrm{H}_{1:} \text { Katılımcıların }(\mathrm{X}) \text { 'e yönelik görüşlerinde }(\mathrm{Y}) \text { değişkenine } \\
\text { göre anlamlı bir farklılık vardır. }\end{array}$} \\
\hline $\mathbf{X} / \mathrm{Y}$ & $\begin{array}{l}\text { (1) Medeni } \\
\text { Durum }\end{array}$ & $\begin{array}{l}\text { (2) Yabanci } \\
\text { Dil Durumu }\end{array}$ \\
\hline \multirow{2}{*}{$\begin{array}{l}\text { Girişimci Olmada Etkili Olan } \\
\text { Sebepler }\end{array}$} & $\begin{array}{l}\text { Sig. (2-tailed) } \\
0,661>0,05\end{array}$ & $\begin{array}{l}\text { Sig. } \\
\text { (2-tailed) } \\
0,213>0,05\end{array}$ \\
\hline & $\begin{array}{l}\mathrm{H}_{1} \text { Red, } \\
\text { Farklilik } \\
\text { Yoktur }\end{array}$ & $\begin{array}{l}\mathrm{H}_{1} \text { Red, } \\
\text { Farkl1lik } \\
\text { Yoktur }\end{array}$ \\
\hline \multirow{2}{*}{$\begin{array}{l}\text { Girişimcilikte } \\
\text { Faktörleri }\end{array}$} & $\begin{array}{l}\text { Sig. (2-tailed) } \\
0,240>0,05\end{array}$ & $\begin{array}{l}\text { Sig. (2-tailed) } \\
0,551>0,05\end{array}$ \\
\hline & $\begin{array}{l}\mathrm{H}_{1} \text { Red, } \\
\text { Farklilik } \\
\text { Yoktur }\end{array}$ & $\begin{array}{l}\mathrm{H}_{1} \text { Red, } \\
\text { Farkl1lik } \\
\text { Yoktur }\end{array}$ \\
\hline \multirow{2}{*}{$\begin{array}{l}\text { Girişimcilikte } \\
\text { Sorunlar }\end{array}$} & $\begin{array}{l}\text { Sig. (2-tailed) } \\
0,279>0,05\end{array}$ & $\begin{array}{l}\text { Sig. (2-tailed) } \\
0,993>0,05\end{array}$ \\
\hline & $\begin{array}{l}\mathrm{H}_{1} \text { Red, } \\
\text { Farklılik } \\
\text { Yoktur }\end{array}$ & $\begin{array}{l}\mathrm{H}_{1} \text { Red, } \\
\text { Farklılik } \\
\text { Yoktur }\end{array}$ \\
\hline \multirow[b]{2}{*}{$\begin{array}{l}\text { Başarılı Bir Girişimcinin Sahip } \\
\text { Olması Gereken Özellikler }\end{array}$} & $\begin{array}{l}\text { Sig. (2-tailed) } \\
0,091<0,05\end{array}$ & $\begin{array}{l}\text { Sig. (2-tailed) } \\
0,033<0,05\end{array}$ \\
\hline & $\begin{array}{l}\mathrm{H}_{1} \mathrm{Kabul}, \\
\text { Farklılık } \\
\text { Vardır }\end{array}$ & $\begin{array}{l}\mathrm{H}_{1} \text { Kabul, } \\
\text { Farklılık } \\
\text { Vardır } \\
\end{array}$ \\
\hline
\end{tabular}


Yapılan t testi sonucunda; bireylerin medeni durumlarına göre "girişimci olmada etkili olan sebepler" "girişimcilikte motivasyon faktörleri" ve "girişimcilikte karşılaşılan sorunlar" ölçeklerine ait görüş ortalamaları arasında anlamlı bir farklılık olmadığ $(\mathrm{P}>0,05)$ belirlenmiştir. Ancak $(\mathrm{P}=0,091<0,05)$ olduğundan bireylerin medeni durumları ile "başarılı bir girişimcinin sahip olması gereken özellikler" ölçeğine ait görüş ortalamaları arasında anlamlı bir farklılık olduğu belirlenmiştir. Katılımcıların yabanc1 dil bilgisi durumuna göre ise "girişimci olmada etkili olan sebepler", "girişimcilikte motivasyon faktörleri" ve "girişimcilikte karşılaşılan sorunlar" ölçeklerine ait görüş ortalamaları arasında anlamlı bir farklılık olmadığı $(\mathrm{P}>0,05)$ ancak "başarılı bir girişimcinin sahip olması gereken özellikler" ile ilgili ölçek ifadelerine katılım düzeyleri arasında anlamlı bir farklılık olduğu $(\mathrm{P}<0,05)$ belirlenmiştir.

\section{Grafik 1. Katılımcıların Devletten Beklentilerine Yönelik Bulgular}

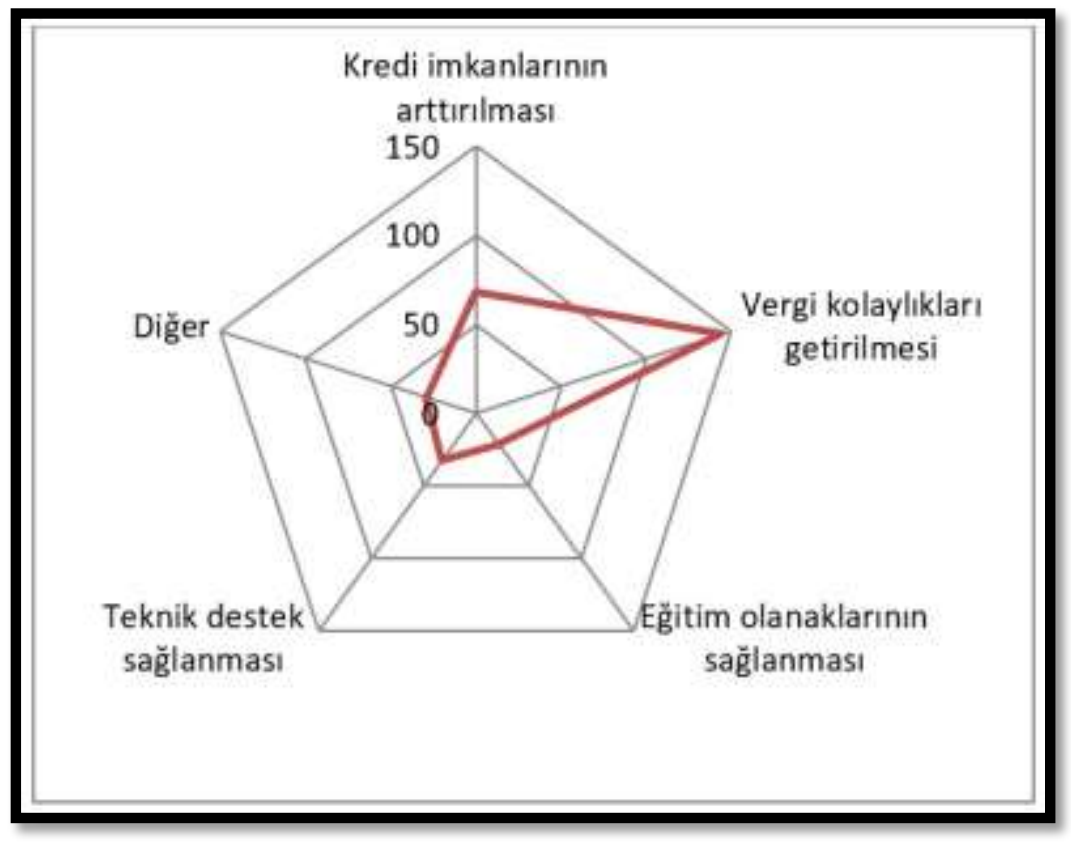

Girişimcilerin devletten öncelikli beklentilerine ilişkin yöneltilen birden fazla seçeneğin işaretlenebildiği sorulara verilen cevaplar radar grafiğinde gösterilmiştir. Kadın girişimcilerin devletten öncelikli olarak vergi konusunda kolaylıklar (f:144) beklediği görülmektedir. Daha sonra sırasıyla kredi imkânlarının artırılması (f:68), teknik destek sağlanması (f:32), diğer münferit talepler (29) ve eğitim olanaklarının sunulması taleplerinin geldiği görülmektedir. 
Tablo 8. Genel Değerlendirme Sorularına Yönelik Bulgular

\begin{tabular}{|c|c|c|}
\hline İşinizle ilgili gelecek planınız nedir? & f & $\%$ \\
\hline Mevcut durumu devam ettirmeyi düşünüyorum & 89 & 47,3 \\
\hline $\begin{array}{l}\text { Ürün ve hizmette çeşitlendirme yaparak büyümeyi } \\
\text { hedefliyorum }\end{array}$ & 79 & 42,0 \\
\hline Farklı sektörlere girmeyi düşünüyorum & 15 & 8,0 \\
\hline İşi bırakmayı düşünüyorum & 1 & 0,5 \\
\hline Diğer & 4 & 2,1 \\
\hline Toplam & 188 & 100,0 \\
\hline \multicolumn{3}{|l|}{$\begin{array}{l}\text { Bir kadın girişimci olarak girişimcilikten önceki } \\
\text { kişisel imajınız ve kendinize olan güveninizin } \\
\text { olumlu yönde geliştiğini düşünüyor musunuz? }\end{array}$} \\
\hline Evet, olumlu yönde gelişti & 163 & 86,7 \\
\hline Hayır, olumlu yönde gelişmedi & 1 & 0,5 \\
\hline Herhangi bir değişiklik olmadı & 24 & 12,8 \\
\hline Toplam & 188 & 100,0 \\
\hline \multicolumn{3}{|l|}{ Girișimciliği diğer kadınlara tavsiye eder misiniz? } \\
\hline Evet, tavsiye ederim & 175 & 93,1 \\
\hline Hayır, tavsiye etmem & 13 & 6,9 \\
\hline Toplam & 188 & 100,0 \\
\hline
\end{tabular}

Tablo 8'de yer alan bilgilere göre kadın girişimcilerin gelecekle ilgili planları arasında, ilk siralarda \%47,3'lük oran ile "mevcut durumu devam ettirmeyi düşünüyorum" ve $\% 42,0$ 'l1k oran ile "ürün ve hizmette çeşitlendirme yaparak büyümeyi hedefliyorum" seçenekleri yer almaktadır. Daha sonra \%8'lik oran ile "farklı sektörlere girmeyi düşünüyorum”, $\% 0,5$ 'lik oran ile "işi bırakmayı düşünüyorum” ve \%2,1'lik oran ile diğer seçeneği yer almaktadır. Bu veriler neticesinde, ankete katılan kadın girişimcilerin büyük çoğunluğunun yürütmekte olduğu girişimcilik faaliyetinden memnun olduğu sonucuna ulaşmak mümkündür. Katılımcıların \%86,7'lik bir kısmının gerçekleştirmiş olduğu girişimcilik faaliyetlerinin kişisel imajını ve özgüvenini geliştirdiğini, \%12.8'lik kısmının herhangi bir etki yaratmadığını düşünmekte olduğu sonucuna ulaşılmaktadır. \%0,5'lik küçük bir kesim ise girişimcilik faaliyetlerinin onlarda imaj ve özgüven kaybı yarattığını düşündükleri görülmektedir. \%86,7 gibi büyük bir çoğunluğun girişimcilik sayesinde olumlu sonuçlar almış olması çevrelerinde bulunan diğer kadınlara rol model olarak, onları girişimciliğe teşvik etmelerine sebep olmaktadır. Katılımcıların \%93,1'lik kısmının girişımciliği diğer kadınlara tavsiye ettiği görülürken, \%6,9'luk bir kısmının ise girişimciliği diğer kadınlara tavsiye etmediği görülmektedir. Elde edilen sonuçlara göre katılımcıların neredeyse tamamının diğer kadınlara girişimciliği tavsiye etmiş olmasının sebebini, girişimciliğin kadınlara sağladığı toplumsal ve ekonomik katkılara bağlamak mümkündür. 
Women Entrepreneurship:

\section{Sonuç}

Yirmi birinci yüzyılın ilk çeyreğinin yaşandığı günümüz küresel rekabet ortamında, teknoloji ve çevresel gelişmeler ekonomik kalkınmanın koşullarını radikal bir şekilde değişikliğge uğratmıştır. İçinde bulunduğumuz pandemi süreci bu süreci daha da hızlandırmaktadır. Öncü toplumların varlıklarını sürdürmek adına klasik kalkınma modellerinden ziyade günümüz koşullarına daha uygun girişimcilik modellerine daha fazla önem verdiği görülmektedir. Kolektif merkeziyetçi yapılardan bireysel yenilikçi düşüncenin daha yüksek fayda sağlama potansiyeline sahip olduğu bilinmektedir. Rekabetin çok farklı boyutlara taşındığı günümüzde girişimcilik fenomeninin sunmuş olduğu firsatlar, gelişmiş ekonomiler tarafından keşfedilmiş ve girişimciliğe yönelik sistematik bir genişleme politikası uygulanmıştır. Bu sürecin sunduğu firsatlardan yararlanmak için özellikle genç ve kadın kitlenin sürece dahil edilmesi çok büyük önem arz etmektedir. Girişimcilik sürecinin kadın girişimciliği açısından ele alınarak yayılması, toplumsal kalkınmanın sağlanmasında çarpan etkisiyle büyük bir sinerji yaratma potansiyeline sahiptir. Bu çalışmanın amacı, belirtilen sinerjiye katkı sunacak motivasyon faktörlerinin yordanmasını konu edinmektedir. Bu amaç doğrultusunda gerçekleştirilen araştırma neticesinde elde edilen veriler değerlendirilerek sonuç ve çözüm önerileri ortaya koyulmuştur.

Çalışma kapsamında ulaştığımız sonuçlara göre; kadın girişimcilerin daha çok 36-41 yaş aralığında bulunan orta yaş grubu içerisinde yer aldıkları ve evli oldukları gözlenmiştir. Evli kadınların sayısının fazla olması girişimcilik faaliyetleri için evliliğin büyük bir engel teşkil etmediğini göstermektedir. Kadın girişimcilerin eğitim durumlarına ait veriler incelendiğinde \%60,7'sinin lisans ve üzeri eğitim aldığ görülmüştür. Bu durum yüksek düzeyde eğitim görmüş kadınların girişimciliğe daha fazla eğilimli olduğu sonucuna ulaşılmasını sağlamıştır. Ayrıca katılımcıların iyi düzeyde eğitim almış olmaları, girişimcilikte başarıya ulaşmalarını sağlayan en önemli unsurlardan biri olması nedeniyle büyük önem arz etmektedir.

Katılımcıların faaliyet gösterdiği sektörlere yönelik bulgular sonucunda, kadınların en çok hizmet sektörü içerisinde yer aldıkları görülmüştür. Hizmet sektörünü kozmetik ve gıda sektörleri takip etmektedir. Kadın girişimcilerin çoğunlukla bu sektörler içerisinde faaliyet göstermelerinin sebebini, bu sektörlerin diğer alanlara kıyasla kadınlara daha uygun olması ile kadınların aile ve iş yaşantısı arasında daha serbest bir şekilde hareket etmelerine olanak sağlaması gibi etkenlere bağlamak mümkündür. Kadın girişimcilerin işletmelerinde çalıştırdığı kişi sayıları değerlendirilecek olursa, verilere göre neredeyse yarısının 1-4 kişi arasında çalışan bulundurması, kadın girişimcilerin çoğunlukla küçük ölçekli işletmelere sahip olmayı ve yerel pazara hitap etmeyi tercih ettiğini gösterir niteliktedir. Katılımcıların işletmelerini kurabilmeleri için gerekli olan finansal kaynağı büyük oranda kişisel birikimlerinden veya ailevi kaynaklardan sağladığı görülmektedir. Bu durum kadınların fazla sermaye gerektirmeyen işlere yönelmelerine sebep olabilmektedir.

Kadın girişimcilerin büyük çoğunluğunun girişimci olmadan önce herhangi bir işte çalışmadığı yani iş hayatı için gerekli olan bilgi ve tecrübeyi, girişimcilik 
faaliyetleriyle ya da aldıkları eğitimler sayesinde elde ettikleri sonucuna varmak mümkündür. Birçok kadın girişimcinin yabancı dil bilgisine sahip olmadığı ulaşılan diğer bulgular arasındadır. Bu durumun kadın girişimcilerin işletmelerini büyüterek, küresel pazara hitap etmelerine engel oluşturacağı söylenebilir.

Katılımcıların girişimcilik üzerine eğitim programlarına katılımlarına bakıldığında, en yüksek oranın eğitim programına katılmayan girişimcilere ait olduğu görülmüştür. Bu sonucu ülkemizde kadın girişimcilere yönelik eğitim programlarının yeterli seviyede olmamasına ve gerçekleştirilen eğitim programlarıyla ilgili kadın girişimciler üzerinde yeteri kadar farkındalık yaratılamamasına bağlamak mümkündür. Birçok kuruluş tarafından kadınlara girişimcilik konusunda eğitimler veriliyor olsa da bu eğitimlerin sayıca arttırılması ve çeşitlendirilmesi gerekmektedir.

Araştırma sonucunda kadınların girişimci olmasında etkili olan sebeplerin başında bilgi ve becerilerini kullanma, hedeflerine ulaşma ve topluma fayda sağlama gibi unsurların yer aldığı görülmüştür. Finansal destek ve teşvikler seçeneğinin en az tercih edilen neden olduğu yani kadınların girişimci olmasında belirleyici bir rol oynamadığı sonucuna ulaşılmıştır. Bu sonucun ortaya çıkmasında pozitif ayrımcılık çerçevesinde kadınlara yeteri kadar finansal destek ve teşvikin sağlanmamasının etkili olduğunu söylemek mümkündür. Kadın girişimciler, başarılı bir girişimcide bulunması gereken en önemli özelliğin dürüstlük olduğunu düşünmektedir. Ayrıca sırasıyla güvenilir olma, zeki ve çalışkan olma, kararlı ve azimli olma, iyi bir yönetim yeteneği ile etkili iletişim becerisine sahip olma gibi özelliklerin başarılı bir girişimcide olması gerektiği kanaatinde oldukları görülmektedir. Duygusal zekâ özelliğinin kadın girişimciler tarafından oldukça az tercih edilmesi, iş hayatında duygusal özelliklerden ziyade aklın ve mantığın ön planda olmasını tercih ettikleri sonucunu doğurmaktadır. Araştırmaya katılan kadın girişimcilerin, işletmelerini kurarken karşılaştıkları sorunların başında "sermaye temini", "bürokratik işlemler" ve "pazarda tanınmamış olma" gibi unsurlar yer almaktadır.

Çalışmanın temel konusunu içeren motivasyonel faktörlerin analizi incelendiğinde, kendini gerçekleştirme isteğinin kadınları girişimciliğe motive eden en önemli faktör olduğu görülmektedir. Kadınların özellikle iş hayatında karşılaştıkları cinsiyetçi ve önyargılı yaklaşımlar nedeniyle içlerinde oluşan kendilerini kanıtlama ve başarma isteğinin bu sonucu ortaya çıkardığı söylenebilir. Ayrıca araştırma kapsamında yer alan kadın girişimcilerin büyük bir çoğunluğunun yükseköğrenim gördüğü düşünülürse, almış oldukları eğitimin gereklerini yerine getirerek iş dünyasında başarıya ulaşmak istediklerini söylemekte mümkündür. Kendini gerçekleştirme isteğinden sonra, kadın girişimcilerin en çok para kazanma isteği faktörü ile motive oldukları görülmüştür. $\mathrm{Bu}$ durumun para kazanma isteğinin girişimciliğin temel faktörlerinden biri olmasına ve işletmenin devamlılığı için gerekli olmasına bağlamak mümkündür. Ayrıca bireylerin kişisel ihtiyaçlarını karşılayabilmeleri içinde girişimcilik faaliyetleri neticesinde para kazanmaları gerekmektedir. Motive olunan diğer faktörlerin sırasıyla girişimcilik güdüsü, bağımsız çalışma arzusu, güç elde etme isteği, esnek çalışma saatleri ve sosyal statü edinme isteği olduğu görülmektedir. Kadın girişimcileri en az 
motive eden faktörlerin ise cam tavan sendromu ile işsiz kalma korkusu olduğu görülmüştür. $\mathrm{Bu}$ durum, kadın girişimcilerin bir iş sahibi olmaktan daha çok arzu ettikleri şartlarda ve severek yapabilecekleri bir işte çalışmak istemelerine bağlanabilir.

Oluşturulan hipotez testlerine göre, katılımcıların girişimcilikte motive eden faktörlere yönelik görüşlerinde yaş değişkenine göre farklılık olduğu tespit edilmiştir. $\mathrm{Bu}$ farklılık nedeninin 24-29 yaş grubundaki kadın girişimcilerin yeni dijital teknolojileri daha işlevsel ve yoğun kullanmalarından dolayı gerçekleştiği değerlendirilebilir. Katılımcıların girişimci olmada etkili olan sebeplere yönelik görüşlerinde sermaye kaynağı değişkenine göre farklılık olduğu sonucuna ulaşılmıştır. $\mathrm{Bu}$ farklılığın sermaye kaynağı diğer ortaklar olan girişimciler ile sermaye kaynağı banka kredisi, kişisel ve ailesel kaynaklar olan gruplar arasındaki görüş farklılığına dayandığı tespit edilmiştir. Katılımcıların başarılı bir girişimcinin sahip olması gereken özellikler ve girişimcilikte motive eden faktörlere yönelik görüşlerinde kuruluş yılına göre farklılık olduğu görülmüştür. 2016 ve öncesi kurulan işletme sahibi girişimciler ile 2019 yılında kurulan işletme sahibi girişimcilerin "Girişimcilikte motivasyon faktörleri" ne yönelik görüş ortalamalarında ve 2016 ve öncesi kurulan işletme sahibi girişimciler ile 2017 yılında kurulan işletme sahibi girişimcilerin "başarılı bir girişimcinin sahip olması gereken özellikler” ölçeğine yönelik görüş ortalamaları arasında anlamlı bir farklılık tespit edilmiştir.

Araştırma bulgularına göre kadın girişimcilerin devletten öncelikli olarak vergi konusunda kolaylıklar beklediği görülmektedir. Daha sonra sırasıyla kredi imkânlarının arttırılması, teknik destek sağlanması ve eğitim imkânlarının arttırılmasına yönelik beklentilerinin olduğu sonucuna ulaşılmıştır. Kadın girişimciler kişisel imajlarının ve özgüvenlerinin girişimcilik sayesinde geliştiğini düşünmektedirler. Bundan dolayı katılımcıların neredeyse tamamı girişimciliği diğer kadınlara tavsiye etmektedirler.

Çalışma kapsamında ulaşılan anlamlı sonuçların kadın girişimcilere, girişimci adaylarına ve araştırmacılara yararlı olması beklenmektedir. Girişimcilik, belirli bir bölge, sektör ve grup dışında gelecek açısından tüm toplumu yakından ilgilendiren bir yaşam biçimidir. Araştırmada Konya ilindeki kadın girişimcilerin görüşleri motivasyon açısından ele alınmıştır. Farklı bölgeler, şehirler ve örneklem grupları üzerine yapılacak olan girişimimcilik konulu çalışmalar, tutum karşılaştırmalarına imkân sunarak alana derinlik katma potansiyeline sahiptir. Çalışma amaçları doğrultusunda odaklanılan motivasyon kavramı nicel yöntemle değerlendirilmiştir. Araştırmacılar kadın girişimciliğinde motivasyon konusunu nitel ve karma yöntemler kullanarak da çalışabilirler.

\section{Kaynakça}

Akehurst, G., Simarro, E., ve Mas- Tur, A. (2012). Women entrepreneurship in small service firms: Motivations, barriers and performance. The Service Industries Journal, 32(15), 2489-2505. 
Altuntepe, N. (2019). İslam Ekonomisinde Kadın Girişimciliğinin Yeri ve Önemi: Teorik Bir Yaklaşım. Sakarya İktisat Dergisi, 8(2), 100-130.

Andiç, İ. İ., ve Çakır, H. (2020). Girişimci Kadınlar: Yozgat Örneği. Dünya İnsan Bilimleri Dergisi, (2), 159-180.

Arıkan, C. (2013). Kadın Girişimcilikte Başarı ve Başarıyı Etkileyen Faktörler: Bursa Örneği. Uludağ Üniversitesi Sosyal Bilimler Enstitüsü İşletme Anabilim Dalı Yüksek Lisans Tezi.

Başol, O. (2010). Girişimci Kadın ve Erkeklerin Başarı Algısındaki Farklılıklar: Küçük Ölçekli İşletmelerde Bursa İli Örneği. Uludağ Üniversitesi Sosyal Bilimler Enstitüsü Çalışma Ekonomisi ve Endüstri İlişkileri Anabilim Dalı Yüksek Lisans Tezi.

Bay, M., ve Kulak, H. H. (2020). Girişimcilik Sürecinde Dış Çevre ve Demografik Faktörlerin Rolü. N. K. Erdemir ve O. Aytar (Ed.), Işsletme Perspektifinden Girişimcilik Üzerine Yazılar içinde (ss.133-149). Konya: Eğitim Yayınevi.

Bayraker, N. (2018). Girişimcilik ve Kadın Girişimcilere Destek Olan Kurum ve Kuruluşlar. Okan Üniversitesi Sosyal Bilimler Enstitüsü Bankacılık Anabilim Dalı Yüksek Lisans Tezi.

Bedük, A. (2005). Türkiye'de Çalışan Kadın ve Kadın Girişimciliği. Elektronik Sosyal Bilimler Dergisi, 3 (12), 106-117.

Bozkurt, Ö. ve Yaşar, F. (2018). Girişimci Olma Yolunda Kadın Girişimcileri Anlamak: Kadınlar Ne İster, Akademik Bakış Uluslararası Hakemli Sosyal Bilimler EDergisi, 66, Mart-Nisan, 239-251.

Can, Y., ve Karataş, A. (2007). Yerel Ekonomilerde Kalkınmanın İtici Gücü Olarak Kadın Girişimcilerin Rolü ve Mikro Finansman: Muğla İli Örneği. Selçuk Üniversitesi Karaman İBF Dergisi Yerel Ekonomiler Ö̈zel Sayısı, 6 (8), 251261.

Cansı, E. (2007). Üniversite Öğrencilerinin Girişimcilik Özelliklerinin Belirlenmesi: Süleyman Demirel Üniversitesi Öğrencileri Üzerine Bir Çalışma. Süleyman Demirel Üniversitesi Sosyal Bilimler Enstitüsü İşletme Anabilim Dalı Yüksek Lisans Tezi.

Cici, E. C. (2013). Kadınların Girişimcilik Yolunda Karşılaştıkları Sorunların Öz Girişimcilik Yetenekleri Üzerindeki Etkisi: Konya İlinde Bir Araştırma. Selçuk Üniversitesi, Sosyal Bilimler Enstitüsü, İşletme Anabilim Dalı Yüksek Lisans Tezi. 
Çakmak, Ö. (2019). Kadın girişimciliği- Malatya örneği. Fırat Üniversitesi / Sosyal Bilimler Enstitüsü, Girişimcilik ve İnovasyon Yönetimi Ana Bilim Dalı Yüksek Lisans Tezi.

Çiçek, A. (2019). Anadolu'da Kadın Girişimciliği ve Profili: Iş̧ Kurma Süreçleri ve Sonrasında Yaşanan Sorunlar: Sivas İli Örneği. Gazi Osmanpaşa Üniversitesi, Sosyal Bilimler Enstitüsü, İşletme Ana Bilim Dalı Yüksek Lisans Tezi.

Efe, M. N. (2016). Girişimcilikte Temel Prensipler. Kocaeli: Umuttepe Yayınları.

Erdun, Ş. (2011). Girişimcilerin Risk Alma Eğilimi ve Kendine Güven Özellikleri Üzerine Bir Çalışma: Zonguldak Örneği. Zonguldak Karaelmas Üniversitesi Sosyal Bilimler Enstitüsü İşletme Anabilim Dalı Yüksek Lisans Tezi.

Ersezer, G. (2019). Kadın Girişimcilerin Sorunları Van İli Örneği. Van Yüzüncü Yıl Üniversitesi Sosyal Bilimler Enstitüsü İşletme Ana Bilim Dalı Yüksek Lisans Tezi.

Kaygın, E., ve Güven, B. (2013). Farklı Boyutlarıyla Kadın Girişimcilik. İstanbul: Veritos Akademi Yayınevi.

Keskin, S. (2013). Türkiye'de Kadın Girişimciliğinin İstihdam Yaratmada ki Rolü. İstanbul Üniversitesi Sosyal Bilimler Enstitüsü İktisat Ana Bilim Dalı Doktora Tezi.

Keskin, S. (2014). Türkiye'de Kadın Girişimcilerin Durumu, Girişimcilik ve Kalkınma Dergisi, 9(1), 72-94.

Kıray, İ. (2019). Motivasyon Faktörlerinin Satış Personelinin Motivasyonu ve Performansı Üzerindeki Etkisini İncelemeye Yönelik Bir Araştırma. Çanakkale Onsekiz Mart Üniversitesi Sosyal Bilimler Enstitüsü İşletme Anabilim Dalı Yüksek Lisans Tezi.

Koçel, T. (2018). İşletme Yöneticiliği, İstanbul: Beta Basım Yayım.

Narin, M., Marşap, A., ve Gürol, M. A. (2006). Kadın Girişimciliğinin Maksimizasyonunu Hedefleme: Uluslararası Arenada Örgütlenme ve Ağ Oluşturma. Gazi Üniversitesi İ̈BF Dergisi, 8 (1), 65-78.

Orhan, M. ve Scott, D. (2001). Why women enter into entrepreneurship: an explanatory model, Women in Management Review, Vol. 16 No. 5, pp. 232-247. https://doi.org/10.1108/09649420110395719

Özdemir. A. A. (2010). Potansiyel Girişimci Olan Kadınların Motivasyon Faktörleri ve Eskişehir'de Bir Araştırma. Ege Akademik Bakış, 10 (1), 117-139. 
Özgür, G. (2019). Türkiye’deki Kadın Girişimcilerin Finansman Kaynaklarına Erişim Olanaklarının Analizi. Beykent Üniversitesi Sosyal Bilimler Enstitüsü İşletme Anabilim Dalı Yüksek Lisans Tezi.

Öztürk, M. D. (2016). Türkiye’de Kadın Girişimcilik: Kadınları Girişimciliğe Yönelten Faktörler, Karşılaştıkları Sorunlar ve Çözüm Önerileri. İstanbul Ticaret Üniversitesi Dış Ticaret Enstitüsü Uluslararası Ticaret Anabilim Dalı Yüksek Lisans Tezi.

Özyılmaz, A. M. (2016). Türkiye'de Kadın Girişimciliği ve Girişimci Kadınların Karşılaşıtıları Sorunlar Üzerine Bir Araştırma. Nevşehir Hacı Bektaş Veli Üniversitesi Sosyal Bilimler Enstitüsü Sosyoloji Anabilim Dalı Yüksek Lisans Tezi.

Raghuvanshi, J., Agrawal, R., ve Ghosh, P. K. (2017). Analysis of barriers to women entrepreneurship: The DEMATEL approach. The Journal of Entrepreneurship, 26(2), 220-238.

Sinanoğlu, E. (2005). Kadın Girişimciler Kavramı ve Serbest Meslek Mensubu Kadın Girişimcilere İlişkin Konya İlinde Uygulamalı Bir Araştırma. Selçuk Üniversitesi Sosyal Bilimler Enstitüsü İşletme Anabilim Dalı Yüksek Lisans Tezi.

Soysal, A. (2010a). Kadın Girişimcilerin Özellikleri, Karşılaştıkları Sorunlar ve İş Kuracak Kadınlara Öneriler: Kahramanmaraş İlinde Bir Araştırma. Eskişehir Osmangazi Üniversitesi IİBF Dergisi, 5(1), 71-95.

Soysal, A. (2010b). Türkiye'de Kadın Girişimciler: Engeller ve Fırsatlar Bağlamında Bir Değerlendirme. Ankara Üniversitesi Sosyal Bilimler Fakültesi Dergisi, 65 (1), 85-113.

Şahin, E. (2006). Kadın Girişimcilik ve Konya İlinde Kadın Girişimcilik Profili Üzerine Bir Uygulama. Selçuk Üniversitesi Sosyal Bilimler Enstitüsü İşletme Anabilim Dalı Yüksek Lisans Tezi.

Şimşek, Ş., ve Çelik, A. (2018). Yönetim ve Organizasyon. Konya: Eğitim Kitabevi.

Wu, J., Li, Y., ve Zhang, D. (2019). Identifying women's entrepreneurial barriers and empowering female entrepreneurship worldwide: a fuzzy-set QCA approach. International Entrepreneurship and Management Journal, 15(3), 905-928.

Yağcı, F., ve Bener, Ö. Girişimci Kadınların Demografik ve Genel Karakteristikleri ile Kadınları Girişimciliğe Motive Eden Faktörler. Ankara Bilig, 1(33), 85-10. 
Yaşar, F. (2017). Düzce İlinde Kadın Girişimcilik Profilinin Belirlenmesi. Düzce Üniversitesi Sosyal Bilimler Enstitüsü İşletme Anabilim Dalı Yüksek Lisans Tezi.

Yeşilçimen, P. (2020), Turizm Sektöründe Girişimcilik. N. K. Erdemir ve O. Aytar (Ed.), Isşletme Perspektifinden Girişimcilik Üzerine Yazılar içinde (ss.287-313). Konya: Eğitim Yayınevi.

Yetim, N. (2002). Sosyal Sermaye Olarak Kadın Girişimciler: Mersin Örneği. Ege Akademik Bakış Ekonomisi İşletme Uluslararası İlişkiler ve Siyaset Bilimi Dergisi, 2 (2), 79-92. 